Review

\title{
The emerging molecular pathogenesis of neuroblastoma: implications for improved risk assessment and targeted therapy
}

\author{
Nadine Van Roy, Katleen De Preter, Jasmien Hoebeeck, Tom Van Maerken, Filip Pattyn, \\ Pieter Mestdagh, Joëlle Vermeulen, Jo Vandesompele and Frank Speleman
}

Address: Center for Medical Genetics, Ghent University Hospital, De Pintelaan 185, B-9000 Ghent, Belgium.

Correspondence: Frank Speleman. Email: franki.speleman@ugent.be

\begin{abstract}
Neuroblastoma is one of the most common solid tumors of childhood, arising from immature sympathetic nervous system cells. The clinical course of patients with neuroblastoma is highly variable, ranging from spontaneous regression to widespread metastatic disease. Although the outcome for children with cancer has improved considerably during the past decades, the prognosis of children with aggressive neuroblastoma remains dismal. The clinical heterogeneity of neuroblastoma mirrors the biological and genetic heterogeneity of these tumors. Ploidy and MYCN amplification have been used as genetic markers for risk stratification and therapeutic decision making, and, more recently, gene expression profiling and genome-wide DNA copy number analysis have come into the picture as sensitive and specific tools for assessing prognosis. The application of new genetic tools also led to the discovery of an important familial neuroblastoma cancer gene, $A L K$, which is mutated in approximately $8 \%$ of sporadic tumors, and genomewide association studies have unveiled loci with risk alleles for neuroblastoma development. For some of the genomic regions that are deleted in some neuroblastomas, on $1 p, 3 p$ and $11 q$, candidate tumor suppressor genes have been identified. In addition, evidence has emerged for the contribution of epigenetic disturbances in neuroblastoma oncogenesis. As in other cancer entities, altered microRNA expression is also being recognized as an important player in neuroblastoma. The recent successes in unraveling the genetic basis of neuroblastoma are now opening opportunities for development of targeted therapies.
\end{abstract}

\section{Neuroblastoma: current knowledge and clinical characteristics}

Neuroblastoma (NB) is the most common extra-cranial solid tumor of childhood. It has an incidence of 1 to 5 per million children per year and it is responsible for approximately $15 \%$ of all childhood cancer mortality. NBs originate from immature sympathetic nervous system cells, the so-called neuroblasts. Most NBs (90\%) are diagnosed before the age of 5 years, and the median age of occurrence is approximately 22 months [1]. The vast majority of tumors arise sporadically, although some familial cases are described. Most of the tumors are found in the abdomen (65\%), often in the adrenal medulla, or elsewhere in the human body where sympathetic nervous system components are present [2]. NBs belong to the subgroup of small round blue cell tumors and can often pose a challenge to the pathologist because of their similarities with lymphomas, rhabdomyosarcomas, the Ewing family of tumors and desmoplastic round cell tumors.

NB tumors are divided into different stages according to the localization and extension of the primary tumor and the absence or presence of distant metastases. The International Neuroblastoma Risk Grouping Staging System takes into account the extent of disease at diagnosis as well as risk factors and stages defined using imaging to classify NBs from patients from all over the world in a uniform manner [3,4]. Metastatic tumors (stage M) have a dismal prognosis, whereas patients with locoregional tumors (L1 and L2) usually have an excellent outcome. Stage Ms tumors (where 's' stands for special and metastatic disease is confined to skin, liver and/or bone marrow) are characterized by spontaneous regression or differentiation even without any form of therapy. Although localized disease can be treated by surgery alone, the standard therapy for patients with metastatic disease usually comprises intensive induction chemotherapy, local surgery and myeloablative chemotherapy followed by autologous stem cell transplant, external radiotherapy and retinoic acid treatment. The overall survival rate for children with metastatic NB is approximately $40 \%$, despite this intensive multimodal therapy. The survival of children with NB also correlates strongly with age at diagnosis. Children under 1 year at diagnosis usually have a favorable prognosis, whereas prognosis of older children presenting with $\mathrm{NB}$ is poor.

Currently, there are worldwide efforts to construct a robust risk stratification system. Before any treatment, patients 
will be put into a risk category, according to a combination of parameters such as age (younger or older than 18 months), stage, pathology, MYCN status, other genetic aberrations such as 11q loss and ploidy [3,4] (see below). The use of the International Neuroblastoma Risk Groups will allow international comparisons of different risk-based therapeutic approaches in the same patient population and greatly facilitate joint international collaborative studies in NB. Elucidation of the molecular pathways involved will enable researchers to stratify the disease and to adapt therapy.

\section{Genomic analysis of neuroblastoma: an historical perspective}

The clinically heterogeneous nature of NB is also reflected, in part, by its biological and genetic heterogeneity. During the past decade, several genetic aberrations have been discovered in NB primary tumors and cell lines that have been shown to correlate with the various clinical features. Moreover, genetic and molecular findings are now routinely incorporated into therapeutic decision making [5]. Below, the most important genetic defects that have been detected in NB are briefly discussed.

\section{Ploidy}

According to their DNA index, NBs can be divided into a group with a near-diploid nuclear DNA content (about $45 \%$ of NBs) and those with a near-triploid DNA content (about $55 \%$ ). DNA index is a prognostic marker for patients younger than 2 years who have disseminated disease [2,6-8]. It was suggested that a near-triploid DNA content, which is found more often in localized or Ms NB, was due to the fact that these tumors have a fundamental defect in mitosis leading to gains and losses of whole chromosomes, whereas locoregional or metastatic tumors with a neardiploid DNA content have a fundamental defect in genome stability leading to chromosomal rearrangements such as unbalanced translocations [2,9].

\section{MYCN amplification}

The MYCN oncogene (located on chromosome 2p24; ' $\mathrm{N}$ ' stands for neuroblastoma-derived) was found to be amplified in 20 to $25 \%$ of NBs, and is usually present in the form of double-minutes (chromosome fragments) or homogeneously staining regions (Figure 1) [10]. The MYCN gene encodes a transcription factor that forms heterodimers with the MAX protein [11]. Evidence for a direct involvement in the development of NB was obtained through the construction of a mouse NB model in which a human MYCN cDNA was placed under the control of a tyrosine hydroxylase promoter, leading to development of NB [12]. Amplification of the $M Y C N$ gene is most often found in high-stage tumors and is a marker for poor outcome [13,14].

How MYCN amplification contributes to this aggressive phenotype remains mainly unknown. Although $M Y C N$ regulates a large number of downstream genes, only a handful of key targets have yet been identified. Interestingly, high $M Y C N$ target gene expression is not restricted to $M Y C N$-amplified NBs but is also apparent in high-stage $M Y C N$ non-amplified tumors, indicating that common pathways are altered in high-stage tumors [15].

\section{Chromosome 1p loss}

Deletion of the short arm of chromosome 1 has been detected in approximately 25 to $35 \%$ of primary NBs [16]. This finding suggests the presence of one or more tumor suppressor gene(s) in this chromosome region. In the past, many attempts were made in order to delineate a shortest region of deletion (SRD) on 1p36 [17-22]. The SRD is currently defined to 1p36.31 (a region of approximately $2 \mathrm{Mb}$ ) $[16,20]$. One of the most promising candidate $\mathrm{NB}$ suppressor genes in this region is $\mathrm{CHD}_{5}$ (Figure 1). This gene is a member of the chromatin remodeling family and is expressed mostly in the nervous system [23]. The mouse Chd5 gene was found to control proliferation, senescence and apoptosis through the p19Arf-p53 pathway and was therefore validated as a mouse tumor suppressor gene [24]. Fujita et al. [25] found that human CHD5 expression was low in NB cell lines and in tumors harboring a chromosome 1p deletion. Moreover, they identified $\mathrm{CHD}_{5}$ promoter hypermethylation in the investigated NB cell lines and performed clonogenicity and tumorigenicity experiments. As a result, $\mathrm{CHD}_{5}$ could be defined as a valid chromosome 1p tumor suppressor gene. A second region of deletion on chromosome $1 \mathrm{p} 36$ was defined by a $500 \mathrm{~kb}$ homozygous deletion in a NB cell line (1p36.2) [26]. Within this chromosome region, the $K_{I F 1} B$ gene, a member of the kinesin 3 family, was identified as a haploinsufficient candidate tumor suppressor gene (Figure 1) [27].

Deletion of chromosome 1p sequences is more common in high-stage tumors and is usually associated with $M Y C N$ amplification. The prognostic significance of $1 p$ loss has long been controversial but current evidence suggests that allelic loss of $1 \mathrm{p} 36$ sequences predicts an increased risk of relapse in patients with localized tumors [28-30].

\section{Chromosome 17q gain}

Gain of chromosome $17 \mathrm{q}$ is the most common genetic aberration, occurring in approximately $80 \%$ of NBs $[31,32]$. It often results from unbalanced translocations with chromosome 1p or chromosome 11q [32-34], although other partner chromosomes can be involved. The involvement of chromosome 1 and chromosome 17 in the etiology of NB was further reinforced by the identification of a constitutional balanced $t(1 ; 17)$ translocation in a patient with NB [35-37]. The chromosome 17q breakpoints are not confined to one cytogenetic band but are scattered throughout the long arm of chromosome 17 [38]. On the basis of these findings, the presence of one or more dosagesensitive genes on $17 \mathrm{q}$ implicated in NB seems the most 


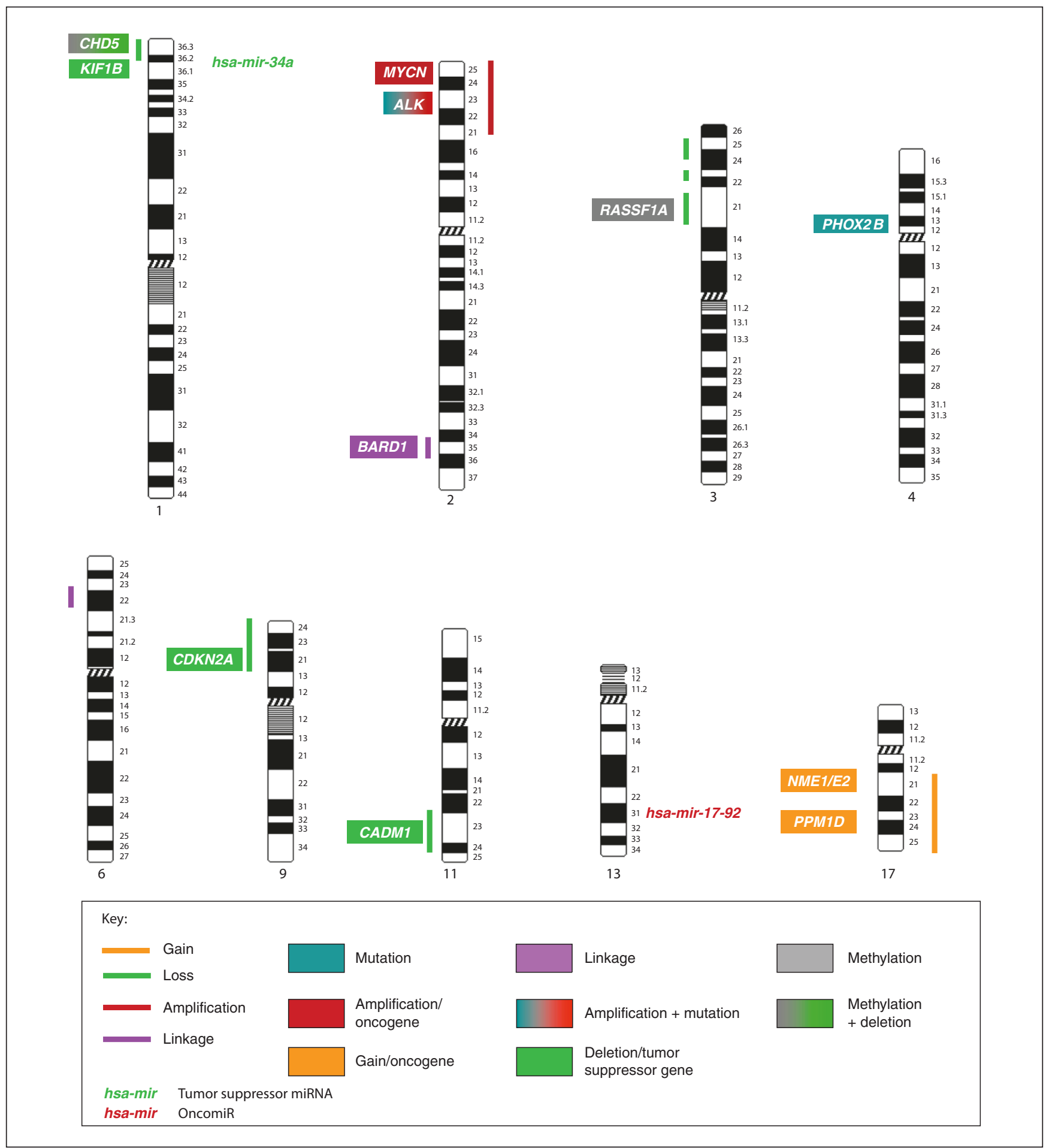

Figure 1

A schematic overview of chromosome regions and genes known to be involved in neuroblastoma oncogenesis. This overview is not comprehensive, and only those regions and genes mentioned in the article are indicated. Gene abbreviations: $A L K$, anaplastic lymphoma receptor tyrosine kinase; BARD1, BRCA1 associated RING domain 1; CADM1, cell adhesion molecule 1; CDKN2A, cyclin dependent kinase inhibitor 2A; CHD5, chromodomain helicase DNA binding protein 5; KIF1B, kinesin family member 1B; MYCN, v-myc myelocytomatosis viral related oncogene, neuroblastoma derived; NME1/E2, non-metastatic cells 1, protein (NM23A) expressed in/non-metastatic cells 2, protein (NM23A) expressed in; PHOX2B, paired-like homeobox 2b; PPM1D, protein phosphatase 1D magnesium-dependent, delta isoform; RASSF1A, Ras association (RalGDS/AF-6) domain family member 1. 
plausible hypothesis. Near-triploid tumors have often gained a whole extra chromosome 17, whereas unbalanced 17q gain is characteristic for near-diploid tumors. Chromosome 17q gain was found to be the strongest independent parameter for poor outcome, whereas whole-chromosome 17 gain was associated with good prognosis [39,40]. Several genes have already been proposed as candidate dosage-sensitive oncogenes, such as NME1, NME2 and PPM1D (Figure 1) [41,42].

\section{Chromosome 11q loss}

Deletions of the long arm of chromosome 11 have been identified in 15 to $22 \%$ of primary NBs $[28,40,43]$. Chromosome 11q deletions are often found in high-stage tumors without $M Y C N$ amplification and with intact chromosome 1p. Chromosome 11q loss was shown to be associated with reduced time of progression-free survival $[28,44]$. Recently, two common regions of deletion on the long arm of chromosome 11 were delineated and CADM1 was identified as a candidate chromosome 11q tumor suppressor gene (Figure 1) [45-47].

\section{Chromosome 3p loss}

Chromosome $3 p$ loss is often found in association with 11q loss and typically occurs in tumors without MYCN amplification or $1 p$ deletion [43,48-51]. Furthermore, tumors with $3 p$ loss are a hallmark of NB patients with older age at diagnosis, suggesting that $3 p$ loss is a late event in NB oncogenesis [40]. At present, three common regions of deletions on the short arm of chromosome 3 can be delineated [52]. Two of these SRDs were found to coincide with SRDs defined in more common cancers, such as breast and lung cancer [52]. These regions contain several candidate tumor suppressor genes, including the RASSF1A gene (Figure 1).

\section{Familial neuroblastoma and genetic susceptibility and risk alleles}

Familial forms of NB are rare, accounting for only $1 \%$ of all cases [53,54]. Analysis of the pedigree structure of the rare familial cases suggests a dominant mode of inheritance with low or incomplete penetrance. Familial NB patients are often diagnosed with multiple or multifocal tumors and at a younger age than are patients with sporadic NB, consistent with Knudson's two-hit hypothesis: familial patients already carry one genetic hit in all their cells, whereas sporadic NB patients have to accumulate two genetic hits in the somatic tissue [55]. Loss-of-function germline mutations have been detected in the $\mathrm{PHOX}_{2} \mathrm{~B}$ gene, a neurogenesis regulator gene that is mutated in congenital central hypoventilation syndrome (Figure 1) [56-58].

Recently, a whole-genome linkage scan in a panel of NB pedigrees identified a significant linkage signal at 2p23-24. Resequencing of candidate genes in this region identified germline mutations in the $A L K$ gene (Figure 1) [59].
Subsequently, somatic $A L K$ mutations or amplifications were identified in about $8 \%$ of all sporadic NB tumors [59-63]. ALK is a member of the tyrosine kinase family and mutations result in constitutive activation of the gene. These findings demonstrate that germline mutations in $A L K$ are the main cause of familial NB and that they could offer new targeted therapeutic opportunities for NB patients, in addition to those suggested by somatic mutations.

\section{Genome-wide association studies of neuroblastoma}

Genome-wide association studies (GWASs) have shown a significant association between clinically aggressive NBs and common single nucleotide polymorphisms (SNPs) or variants at chromosome region 6p22 (Figure 1), suggesting that these variants are associated with a susceptibility to $\mathrm{NB}$, especially to metastatic disease with $M Y C N$ amplification and a high probability of relapse [64]. In a follow-up GWAS, a second susceptibility locus for the development of aggressive NB tumors was identified, the $B A R D 1$ locus at 2 2935 (Figure 1) [65]. The susceptibility for NB was linked to six SNPs located in introns 1, 3 and 4 of BARD1 [65]. The BARD1 protein heterodimerizes with the familial breast cancer gene product BRCA1 [66] and is essential for the tumor suppressor activity of $B R C A 1$.

\section{Whole-genome DNA copy number analysis}

Whole-genome analysis techniques such as comparative genomic hybridization (CGH) or array $\mathrm{CGH}$ enable the study of DNA copy number gains and losses over the entire genome in one single experiment [67] and have, since their introduction, been used extensively in the genomic profiling of a great variety of solid tumors [68]. Array CGH analysis has been used to classify primary NB tumors into specific genomic subgroups and to correlate these findings with clinical outcome [68-70]. As already mentioned, two major subgroups have been identified in NB: near-triploid tumors, showing only numerical chromosome aberrations and no structural defects, and near-diploid tumors, characterized by MYCN amplification and 1p deletion or deletions in 11q and 3p [43,48,50,51,71]. Subtype 1 tumors are associated with an excellent outcome, even in older patients and metastatic tumors, whereas the subtype 2 tumors are associated with a higher frequency of relapse $[69,70,72,73]$. Even in multivariate analysis, the genomic profile (the classification into genomic subtype) is still statistically significant and therefore provides useful additional prognostic information [40,69]. Array CGH profiles of more than 1,000 tumors are now available and open the way to more in-depth meta-analysis of the genomic profile of NB, especially enabling the search for more infrequent but important genomic changes.

\section{Gene expression profiling as a discovery and prognostic tool}

As NB is a tumor with a remarkably heterogeneous clinical course, one of the main challenges is an accurate outcome 
prediction, enabling a better choice of risk-related therapy. As differences in outcome are considered to reflect underlying genetic and biological characteristics that affect mRNA gene expression profiles, several genome-wide mRNA expression profiling studies have been undertaken to establish a gene-expression-based classifier for improved outcome prediction in patients with NB [74-78]. Berwanger and colleagues [79] reported that expression of the $F Y N$ gene predicts long-term survival independently of $M Y C N$ amplification. Moreover, the authors could show that expression of active FYN kinase induces differentiation and growth arrest of NB cells in culture. Recently, a 42-gene expression signature was established using an innovative data-mining approach using expression profiles of four published microarray studies (De Preter K, personal communication; permission was obtained; De Preter K is co-author on this review) and an extensive review of literature on individual genes with prognostic value. This classifier was validated in silico on three independent and unpublished datasets. The gene set was extended by re-analysis of three further published microarray studies and by an extensive literature screening for single candidate prognostic genes, yielding a list of 59 potential prognostic genes in total. By measuring gene expression using quantitative reverse transcriptase PCR, this set of 59 genes was profiled in 579 patients, the largest NB patient series so far [80]. This showed that the signature was a strong independent risk predictor and could identify patients with increased risk in the current risk groups, that is, patients in the current high risk group, who were being treated with high dose chemotherapy, and patients in the low risk group, who were usually treated by surgery [80].

So far, most gene expression profiling studies have focused on the identification of prognostic signatures. However, careful scrutiny of the prognostic gene list and functional analyses might reveal genes that have a role in NB pathogenesis and, therefore, could serve as potential therapeutic targets or point at pathways involved in cancer that could be targeted by new therapies. Furthermore, inclusion of transcriptome information on the cells of origin of $\mathrm{NB}$ (sympathetic nervous system progenitors) can add additional power to mining of tumor gene expression data. Indeed, transcriptome profiling of fetal neuroblasts and comparison with tumor data highlighted a series of interesting candidate genes and pathways that were assumed to be involved in NB pathogenesis (such as $A L K, K I F_{1} B$ and $C A D M 1$ ) [81]. In a more recent analysis, gene lists obtained through mining of neuroblast and NB gene expression profiles were used in conjunction with the Connectivity Map tool [82], which allows prediction of therapeutic compounds that could be of use for the cells under study [83].

Future studies will certainly be directed towards further integrated analysis of mRNA, microRNA (miRNA) and gene copy number profiling, in order to obtain further insights into the complex molecular pathways that govern pathogenesis of the different subtypes of NB.

\section{Methylation profiling of candidate tumor suppressor genes}

In cancer cells, aberrant tumor suppressor gene silencing can occur as a result of alterations in methylation patterns. Over the past years, several abnormally methylated genes have been described in NB. These genes encode proteins that are involved in various cellular pathways, including apoptosis (the protease CASP8 and the adaptor TMS1), the cell cycle (the cyclin-dependent kinase inhibitor CDKN2A, the cyclin CCND2 and stratifin (SFN)), differentiation (the retinoic acid receptor RARB2), and invasion and metastasis (the cadherin CDH1) [84]. Some significant associations of epigenetic signatures with clinical and biological parameters have been found [85-89]. Besides single gene associations, Alaminos et al. [86] demonstrated that clustering of neuroblastic tumor samples by the methylation pattern of ten genes allowed the identification of several clinically relevant groups of tumors. Global methylation studies have demonstrated that a methylator phenotype, characterized by the methylation of multiple $\mathrm{CpG}$ islands, is a hallmark of NBs with poor prognosis [85]. Recently, the presence of methylation markers in serum of NB patients has been described as an indicator of prognosis and therapy efficacy $[90,91]$.

These findings have demonstrated the clinical relevance of promoter hypermethylation in the pathogenesis of NB. Global profiling of gene promoter hypermethylation to identify genome-wide aberrantly methylated genes is therefore warranted in order to further understand $\mathrm{NB}$ pathogenesis and to identify new prognostic methylation markers for the optimization of therapeutic strategies.

\section{miRNA profiling in neuroblastoma}

During the past decade, small non-coding RNAs have emerged as a new and unexpected piece in the complex puzzle of the transcriptome. One set of non-coding RNAs, the miRNAs, has been studied heavily in the context of cancer. These tiny molecules are 22 to 25 nucleotides in length and function as negative regulators of gene expression. Their expression correlates to prognosis, diagnosis and response to treatment and, like coding genes, they can function as oncogenes or tumor suppressors [92].

A key role for miRNAs in NB is also becoming apparent. Chen and Stallings [93] were the first to show that different prognostic subgroups of NBs are characterized by specific miRNA expression profiles [93]. One of the major factors driving this differential expression is $M Y C N$ amplification. Interestingly, the majority of these miRNAs are downregulated in the $M Y C N$-amplified tumor samples. These findings are in line with the reported global downregulation of miRNA expression in poorly differentiated cells $[85,94]$. 
miRNAs that are activated by MYCN belong to the three paralogous clusters miR-17-92 (a cluster of seven miRNAs), $m i R-106 a$ and $m i R-106 b[95,96]$. These clusters show a high level of sequence similarity to each other and are derived from a single gene that underwent a series of duplications, mutations and deletions during evolution. Overexpression of the miR-17-92 cluster has been reported in several cancer types and is responsible for boosting cell cycle progression and blocking apoptotic signaling (Figure 1) [97-99]. In NB, we and others have shown that miR-17-92 expression is directly activated by MYCN through a direct binding to conserved E-box elements in the miR-17-92 promoter [100] (Mestdagh P, personal communication; permission was obtained; Mestdagh $\mathrm{P}$ is co-author on this review). This results in a strong increase in tumorigenesis both in vitro and in vivo by downmodulation of p21, a negative modulator of the cell cycle, and $B I M$, a proapoptotic gene [100]. Treatment with antagomir-17 (an engineered miRNA inhibitor) restores expression of p21 and BIM and abolishes the growth of $M Y C N$-amplified and therapy-resistant $\mathrm{NBs}$ in vivo, indicating that targeted miR-17-92 inhibition might be useful in the treatment of NB.

MYCN itself is also a target of miRNA molecules: $m i R-34 a$, a key effector of the p53-mediated apoptotic response, directly targets MYCN, thereby suppressing MYCN protein expression [101,102]. Interestingly, miR-34a is located within the minimally deleted region on chromosome 1 p36 and shows a decreased expression in NBs with a 1p36 deletion (Figure 1) [103]. Given the frequent association between MYCN amplification and 1p36 deletion, loss of miR-34a expression might be essential in maintaining high MYCN protein levels in tumor cells. Indeed, exogenous $m i R-34 a$ overexpression results in decreased NB cell growth through increased apoptosis and decreased DNA synthesis [101,102].

It is becoming clear that miRNAs have a central role in the pathogenesis of $\mathrm{NB}$, but further research is warranted in order to get more profound insight into the complex regulatory interplay between coding and non-coding genes. Although we are only beginning to understand the role of miRNAs, new small and long non-coding RNAs are being discovered that may prove to be other missing pieces in the cancer puzzle.

\section{New opportunities for targeted therapy of high-risk neuroblastoma}

About half of all children with NB are classified as highrisk patients, for whom conventional treatment options achieve a disappointingly low overall survival rate of less than $40 \%$ [104]. It is therefore imperative to translate the increasing knowledge of NB biology into development of novel, targeted therapeutic approaches. We will focus here on three key oncogenes (MYCN, MDM2 and $A L K$ ) that are excellent targets for molecular intervention in NB. A detailed overview of other promising preclinical investigations and ongoing clinical trials for treatment of highrisk NB can be found elsewhere [105].

The MYCN transcription factor has attracted considerable interest as a potential drug target in view of its frequent amplification and oncogenic role in aggressive NB tumors and its very restricted pattern of expression in normal postnatal cells. These efforts have not yet resulted in a mainstream anticancer therapy, which may in part be explained by difficulties associated with selective pharmacological inhibition of nuclear transcription factors [106], but various strategies aimed at counteracting MYCN activity are actively being pursued. First, several potential smallmolecule inhibitors of MYCN transcriptional function have been identified using a cell-based MYCN reporter gene assay [107]. Similarly, a screen for small molecules that are synthetically lethal with $M Y C$ overexpression has identified various compounds interfering with the MYC pathway at different levels, termed MYRAs (MYC pathway response agents), which have subsequently been shown to also selectively target the MYCN pathway [108,109]. A second group of MYCN-targeting interventions aims at inhibition of $M Y C N$ expression by the use of nucleic-acid-based therapeutics, such as antisense oligonucleotides [110,111] and RNA interference techniques [112,113].

Another appealing approach for molecular therapy of NB is provided by a crucial protein-protein interaction that regulates, to a great extent, the cellular decision between life and death: the physical association between the p53 tumor suppressor protein and its major negative regulator MDM2. Escape from the p53-orchestrated failsafe program is a necessary event for tumorigenesis and is achieved by mutational inactivation of the TP53 gene in approximately half of all human neoplasms. However, NB tumors only rarely present with a TP53 mutation at diagnosis and often rely on an inappropriately increased activity of MDM2 to keep p53 in check [25,114-121]. Consequently, targeted disruption of the p53-MDM2 interaction may be a powerful means of unleashing the potent antitumor capacities of wild-type p53 in NB cells, without inflicting the collateral genotoxic damage associated with conventional chemotherapeutic drugs. Using a low-molecular-weight compound that competes with p53 for binding into a hydrophobic cleft on the surface of MDM2, termed nutlin-3 [122], we have been able to elicit a robust and selective activation of the p53 pathway in NB cells with wild-type p53, leading to $G_{1}$ cell cycle arrest, apoptosis, premature senescence and neuronal differentiation [123]. MDM2 inhibition by nutlin-3 also dramatically sensitizes NB cells to chemotherapy-induced apoptotic cell death [124], and nutlin-3 can reverse P-glycoprotein-mediated multidrug resistance of NB cells regardless of TP53 mutation status [125]. These findings suggest that nutlin-3 may hold promise as a new treatment option for NB. 
A recent breakthrough in our understanding of the pathogenesis of NB is the identification of activating point mutations in the tyrosine kinase domain of the $A L K$ gene as the main cause of familial NB, and implication of these mutations in a substantial fraction of sporadic NB tumors [59-63]. Furthermore, the ALK locus is also a recurrent target of copy number gain or amplification in sporadic NB [59-63,126]. The remarkable success of small-molecule tyrosine kinase inhibitors in other tumor entities, such as imatinib in chronic myeloid leukemia and gefitinib in nonsmall-cell lung cancer, illustrates the vast therapeutic potential buried in targeted inhibition of oncogenically activated tyrosine kinases [127]. NB cells harboring $A L K$ mutation or amplification have been shown to have an absolute requirement for ALK signaling [59-63,128]. Thus, it is expected that selective ALK inhibitors, which are a major focus of current drug development efforts [129], may prove valuable for the treatment of selected NB patients.

\section{Conclusions}

NB is a clinically and genetically heterogeneous disease, with a very variable clinical course and outcome. An essential step towards better understanding of this enigmatic disease is to gain more insights into the (epi)genetic defects and deregulated signaling pathways leading to NB oncogenesis. Genome-wide analyses have enabled researchers to identify recurrent amplifications, gains and losses of genomic regions, allowing further delineation of the genetic heterogeneity of this tumor. At the single gene level, an increasing number of genes and loci have now been identified that are implicated in NB. After many years of NB research, this complex disease now seems to be finally unmasking its disturbed genetic profile, which hopefully soon will allow the development of more efficient and less toxic molecular therapies.

\section{Competing interests}

The authors declare that they have no competing interests.

\section{Authors' contributions}

All authors were involved in the drafting of the manuscript, and each contributed to a particular section.

\section{Acknowledgements}

The authors' work is funded by the Belgian Foundation Against Cancer, the Children Cancer Fund Ghent, the Belgian Kid's Fund and the Foundation Nuovo-Soldati (JV), the Fund for Scientific Research Flanders (KDP, TVM), the Foundation Fournier Majoie pour l'Innovation, the European Union under FP6, and the Belgian program of Interuniversity Poles of Attraction.

\section{References}

1. Schwab M, Westermann F, Hero B, Berthold F: Neuroblastoma: biology and molecular and chromosomal pathology. Lancet Oncol 2003, 4:472-480.

2. Brodeur GM: Neuroblastoma: biological insights into a clinical enigma. Nat Rev Cancer 2003, 3:203-216.

3. Cohn SL, Pearson AD, London WB, Monclair T, Ambros PF, Brodeur GM, Faldum A, Hero B, lehara T, Machin D, Mosseri V,
Simon T, Garaventa A, Castel V, Matthay KK: The International Neuroblastoma Risk Group (INRG) classification system: an INRG Task Force report. J Clin Oncol 2009, 27:289-297.

4. Monclair T, Brodeur GM, Ambros PF, Brisse HJ, Cecchetto G, Holmes K, Kaneko M, London WB, Matthay KK, Nuchtern JG, von Schweinitz D, Simon T, Cohn SL, Pearson AD: The International Neuroblastoma Risk Group (INRG) staging system: an INRG Task Force report. J Clin Oncol 2009, 27: 298-303.

5. Ambros PF, Ambros IM, Brodeur GM, Haber M, Khan J, Nakagawara A, Schleiermacher G, Speleman F, Spitz R, London WB, Cohn SL, Pearson AD, Maris JM: International consensus for neuroblastoma molecular diagnostics: report from the International Neuroblastoma Risk Group (INRG) Biology Committee. Br J Cancer 2009, 100:14711482

6. Bagatell R, Rumcheva P, London WB, Cohn SL, Look AT Brodeur GM, Frantz C, Joshi V, Thorner P, Rao PV, Castleberry $\mathrm{R}$, Bowman LC: Outcomes of children with intermediaterisk neuroblastoma after treatment stratified by MYCN status and tumor cell ploidy. J Clin Oncol 2005, 23:88198827.

7. George RE, London WB, Cohn SL, Maris JM, Kretschmar C, Diller L, Brodeur GM, Castleberry RP, Look AT: Hyperdiploidy plus nonamplified MYCN confers a favorable prognosis in children 12 to 18 months old with disseminated neuroblastoma: a Pediatric Oncology Group study. J Clin Oncol 2005, 23:6466-6473

8. Look AT, Hayes FA, Shuster JJ, Douglass EC, Castleberry RP, Bowman LC, Smith EI, Brodeur GM: Clinical relevance of tumor cell ploidy and $\mathrm{N}$-myc gene amplification in childhood neuroblastoma: a Pediatric Oncology Group study. J Clin Oncol 1991, 9:581-591.

9. Kaneko Y, Knudson AG: Mechanism and relevance of ploidy in neuroblastoma. Genes Chromosomes Cancer 2000, 29:8995.

10. Schwab M, Varmus HE, Bishop JM, Grzeschik KH, Naylor SL, Sakaguchi AY, Brodeur G, Trent J: Chromosome localization in normal human cells and neuroblastomas of a gene related to c-myc. Nature 1984, 308:288-291.

11. Wenzel A, Cziepluch C, Schurmann J, Schwab M: The N-myc oncoprotein is a transcriptional activator and associates with max and RB1 proteins. Prog Clin Biol Res 1994, 385:5966.

12. Weiss WA, Aldape K, Mohapatra G, Feuerstein BG, Bishop JM: Targeted expression of MYCN causes neuroblastoma in transgenic mice. EMBO J 1997, 16:2985-2995.

13. Brodeur GM, Seeger RC, Schwab M, Varmus HE, Bishop JM: Amplification of $\mathrm{N}$-myc in untreated human neuroblastomas correlates with advanced disease stage. Science 1984, 224:1121-1124.

14. Seeger RC, Brodeur GM, Sather H, Dalton A, Siegel SE, Wong KY, Hammond D: Association of multiple copies of the $\mathrm{N}$-myc oncogene with rapid progression of neuroblastomas. N Engl J Med 1985, 313:1111-1116.

15. Westermann $F$, Muth $D$, Benner A, Bauer T, Henrich KO, Oberthuer A, Brors B, Beissbarth T, Vandesompele J, Pattyn F, Hero B, Konig R, Fischer M, Schwab M: Distinct transcriptional MYCN/c-MYC activities are associated with spontaneous regression or malignant progression in neuroblastomas. Genome Biol 2008, 9:R150.

16. White PS, Thompson PM, Gotoh T, Okawa ER, Igarashi J, Kok M, Winter C, Gregory SG, Hogarty MD, Maris JM, Brodeur GM: Definition and characterization of a region of $1 \mathrm{p} 36.3 \mathrm{con}$ sistently deleted in neuroblastoma. Oncogene 2005, 24: 2684-2694.

17. Bauer A, Savelyeva L, Claas A, Praml C, Berthold F, Schwab $M$ : Smallest region of overlapping deletion in 1p36 in human neuroblastoma: a $1 \mathrm{Mbp}$ cosmid and PAC contig. Genes Chromosomes Cancer 2001, 31:228-239.

18. Caron H, Spieker N, Godfried M, Veenstra M, van Sluis P, de Kraker J, Voute P, Versteeg R: Chromosome bands 1p35-36 contain two distinct neuroblastoma tumor suppressor loci, 
one of which is imprinted. Genes Chromosomes Cancer 2001, 30:168-174

19. Martinsson $T$, Sjoberg RM, Hallstensson $K$, Nordling $M$, Hedborg F, Kogner P: Delimitation of a critical tumour suppressor region at distal $1 \mathrm{p}$ in neuroblastoma tumours. Eur J Cancer 1997, 33:1997-2001.

20. Okawa ER, Gotoh T, Manne J, Igarashi J, Fujita T, Silverman KA, Xhao H, Mosse YP, White PS, Brodeur GM: Expression and sequence analysis of candidates for the 1p36.31 tumor suppressor gene deleted in neuroblastomas. Oncogene 2008, 27:803-810

21. Schleiermacher $G$, Peter $M$, Michon J, Hugot JP, Vielh $P$, Zucker JM, Magdelenat $\mathrm{H}$, Thomas G, Delattre O: Two distinct deleted regions on the short arm of chromosome 1 in neuroblastoma. Genes Chromosomes Cancer 1994, 10:275-281.

22. Takeda O, Homma C, Maseki N, Sakurai M, Kanda N, Schwab M, Nakamura Y, Kaneko Y: There may be two tumor suppressor genes on chromosome arm 1p closely associated with biologically distinct subtypes of neuroblastoma. Genes Chromosomes Cancer 1994, 10:30-39.

23. Thompson PM, Gotoh T, Kok M, White PS, Brodeur GM: CHD5, a new member of the chromodomain gene family, is preferentially expressed in the nervous system. Oncogene 2003, 22:1002-1011.

24. Bagchi A, Papazoglu C, Wu Y, Capurso D, Brodt M, Francis D, Bredel $M$, Vogel $\mathrm{H}$, Mills AA: CHD5 is a tumor suppressor at human 1p36. Cell 2007, 128:459-475.

25. Fujita T, Igarashi J, Okawa ER, Gotoh T, Manne J, Kolla V, Kim $\mathrm{J}$, Zhao $\mathrm{H}$, Pawel BR, London WB, Maris JM, White PS, Brodeur GM: CHD5, a tumor suppressor gene deleted from 1p36.31 in neuroblastomas. J Natl Cancer Inst 2008, 100: 940-949.

26. Chen YZ, Soeda E, Yang HW, Takita J, Chai L, Horii A, Inazawa J, Ohki M, Hayashi Y: Homozygous deletion in a neuroblastoma cell line defined by a high-density STS map spanning human chromosome band 1p36. Genes Chromosomes Cancer 2001, 31:326-332.

27. Munirajan AK, Ando K, Mukai A, Takahashi M, Suenaga $Y$, Ohira M, Koda T, Hirota T, Ozaki T, Nakagawara A: KIF1Bbeta functions as a haploinsufficient tumor suppressor gene mapped to chromosome $1 \mathrm{p} 36.2$ by inducing apoptotic cell death. J Biol Chem 2008, 283:24426-24434.

28. Attiyeh EF, London WB, Mosse YP, Wang Q, Winter C, Khazi D, McGrady PW, Seeger RC, Look AT, Shimada H, Brodeur GM, Cohn SL, Matthay KK, Maris JM: Chromosome 1p and $11 \mathrm{q}$ deletions and outcome in neuroblastoma. $N$ Engl J Med 2005, 353:2243-2253.

29. Caron $H$, van Sluis $P$, de Kraker J, Bokkerink J, Egeler $M$, Laureys G, Slater R, Westerveld A, Voute PA, Versteeg R: Allelic loss of chromosome $1 \mathrm{p}$ as a predictor of unfavorable outcome in patients with neuroblastoma. N Engl J Med 1996, 334:225-230.

30. Gehring M, Berthold F, Edler L, Schwab M, Amler LC: The 1p deletion is not a reliable marker for the prognosis of patients with neuroblastoma. Cancer Res 1995, 55:53665369 .

31. Meddeb M, Danglot G, Chudoba I, Venuat AM, Benard J, AvetLoiseau $\mathrm{H}$, Vasseur B, Le Paslier D, Terrier-Lacombe MJ, Hartmann O, Bernheim A: Additional copies of a 25 Mb chromosomal region originating from 17q23.1-17qter are present in $90 \%$ of high-grade neuroblastomas. Genes Chromosomes Cancer 1996, 17:156-165.

32. Van Roy N, Laureys G, Cheng NC, Willem P, Opdenakker G, Versteeg $R$, Speleman $F: 1 ; 17$ translocations and other chromosome 17 rearrangements in human primary neuroblastoma tumors and cell lines. Genes Chromosomes Cancer 1994, 10:103-114.

33. Caron $\mathrm{H}$, van Sluis $\mathrm{P}$, van Roy $\mathrm{N}$, de Kraker J, Speleman $\mathrm{F}$, Voute PA, Westerveld A, Slater R, Versteeg R: Recurrent 1;17 translocations in human neuroblastoma reveal nonhomologous mitotic recombination during the S/G2 phase as a novel mechanism for loss of heterozygosity. Am J Hum Genet 1994, 55:341-347.
34. Savelyeva L, Corvi R, Schwab M: Translocation involving 1p and $17 q$ is a recurrent genetic alteration of human neuroblastoma cells. Am J Hum Genet 1994, 55:334-340.

35. Laureys G, Speleman F, Opdenakker G, Benoit Y, Leroy J: Constitutional translocation $\mathrm{t}(1 ; 17)(\mathrm{p} 36 ; \mathrm{q} 12-21)$ in a patient with neuroblastoma. Genes Chromosomes Cancer 1990, 2: 252-254.

36. Laureys G, Speleman F, Versteeg R, van der Drift P, Chan A, Leroy J, Francke U, Opdenakker G, Van Roy N: Constitutional translocation $t(1 ; 17)(p 36.31-p 36.13 ; q 11.2-q 12.1)$ in a neuroblastoma patient. Establishment of somatic cell hybrids and identification of PND/A12M2 on chromosome 1 and NF1/SCYA7 on chromosome 17 as breakpoint flanking single copy markers. Oncogene 1995, 10:1087-1093.

37. Vandepoele K, Andries V, Van Roy N, Staes K, Vandesompele J, Laureys G, De Smet E, Berx G, Speleman F, van Roy F: A constitutional translocation $t(1 ; 17)(p 36.2 ; q 11.2)$ in a neuroblastoma patient disrupts the human NBPF1 and ACCN1 genes. PLOS ONE 2008, 3:e2207.

38. Vandesompele J, Michels E, De Preter K, Menten B, Schramm A, Eggert A, Ambros PF, Combaret V, Francotte N, Antonacci F, De Paepe A, Laureys G, Speleman F, Van Roy N: Identification of 2 putative critical segments of $17 q$ gain in neuroblastoma through integrative genomics. Int $\mathrm{J}$ Cancer 2008, 122:1177-1182.

39. Bown N, Cotterill S, Lastowska M, O'Neill S, Pearson $A D$, Plantaz D, Meddeb M, Danglot G, Brinkschmidt C, Christiansen H, Laureys G, Speleman F, Nicholson J, Bernheim A, Betts DR, Vandesompele J, Van Roy N: Gain of chromosome arm 17q and adverse outcome in patients with neuroblastoma. $N$ Engl J Med 1999, 340:1954-1961.

40. Vandesompele J, Baudis M, De Preter K, Van Roy N, Ambros $\mathrm{P}$, Bown N, Brinkschmidt C, Christiansen $\mathrm{H}$, Combaret $\mathrm{V}$, Lastowska M, Nicholson J, O'Meara A, Plantaz D, Stallings R, Brichard B, Van den Broecke C, De Bie S, De Paepe A, Laureys G, Speleman F: Unequivocal delineation of clinicogenetic subgroups and development of a new model for improved outcome prediction in neuroblastoma. J Clin Oncol 2005, 23:2280-2299.

41. Adida C, Berrebi D, Peuchmaur M, Reyes-Mugica M, Altieri DC: Anti-apoptosis gene, survivin, and prognosis of neuroblastoma. Lancet 1998, 351:882-883.

42. Godfried $M B$, Veenstra $M, v$ Sluis $P$, Boon $K, v$ Asperen $R$, Hermus MC, v Schaik BD, Voute TP, Schwab M, Versteeg R, Caron HN: The N-myc and c-myc downstream pathways include the chromosome 17q genes nm23-H1 and nm23H2. Oncogene 2002, 21:2097-2101.

43. Vandesompele J, Speleman F, Van Roy N, Laureys G, Brinskchmidt C, Christiansen $\mathrm{H}$, Lampert $\mathrm{F}$, Lastowska $\mathrm{M}$ Bown N, Pearson A, Nicholson JC, Ross F, Combaret V, Delattre O, Feuerstein BG, Plantaz D: Multicentre analysis of patterns of DNA gains and losses in 204 neuroblastoma tumors: how many genetic subgroups are there? Med Pediatr Oncol 2001, 36:5-10.

44. McArdle L, McDermott M, Purcell R, Grehan D, O'Meara A, Breatnach F, Catchpoole D, Culhane AC, Jeffery I, Gallagher WM, Stallings RL: Oligonucleotide microarray analysis of gene expression in neuroblastoma displaying loss of chromosome 11q. Carcinogenesis 2004, 25:1599-1609.

45. Ando K, Ohira M, Ozaki T, Nakagawa A, Akazawa K, Suenaga Y, Nakamura Y, Koda T, Kamijo T, Murakami Y, Nakagawara A: Expression of TSLC1, a candidate tumor suppressor gene mapped to chromosome 11q23, is downregulated in unfavorable neuroblastoma without promoter hypermethylation. Int J Cancer 2008, 123:2087-2094.

46. Michels E, Hoebeeck J, De Preter K, Schramm A, Brichard B, De Paepe A, Eggert A, Laureys G, Vandesompele J, Speleman F: CADM1 is a strong neuroblastoma candidate gene that maps within a $3.72 \mathrm{Mb}$ critical region of loss on 11q23. BMC Cancer 2008, 8:173.

47. Nowacki S, Skowron M, Oberthuer A, Fagin A, Voth H, Brors B, Westermann F, Eggert A, Hero B, Berthold F, Fischer M Expression of the tumour suppressor gene CADM1 is 
associated with favourable outcome and inhibits cell survival in neuroblastoma. Oncogene 2008, 27:3329-3338.

48. Breen CJ, O'Meara A, McDermott M, Mullarkey $M$, Stallings $\mathrm{RL}$ : Coordinate deletion of chromosome $3 p$ and $11 q$ in neuroblastoma detected by comparative genomic hybridization. Cancer Genet Cytogenet 2000, 120:44-49.

49. Ejeskar K, Aburatani H, Abrahamsson J, Kogner P, Martinsson $\mathrm{T}$ : Loss of heterozygosity of $3 p$ markers in neuroblastoma tumours implicate a tumour-suppressor locus distal to the FHIT gene. Br J Cancer 1998, 77:1787-1791.

50. Luttikhuis ME, Powell JE, Rees SA, Genus T, Chughtai S, Ramani P, Mann JR, McConville CM: Neuroblastomas with chromosome 11q loss and single copy MYCN comprise a biologically distinct group of tumours with adverse prognosis. Br J Cancer 2001, 85:531-537.

51. Plantaz D, Vandesompele J, Van Roy N, Lastowska M, Bown N, Combaret V, Favrot MC, Delattre O, Michon J, Benard J, Hartmann O, Nicholson JC, Ross FM, Brinkschmidt C, Laureys G, Caron H, Matthay KK, Feuerstein BG, Speleman F: Comparative genomic hybridization (CGH) analysis of stage 4 neuroblastoma reveals high frequency of $11 \mathrm{q}$ deletion in tumors lacking MYCN amplification. Int $J$ Cancer 2001, 91:680-686.

52. Hoebeeck J, Michels E, Menten B, Van Roy N, Eggert A, Schramm A, De Preter K, Yigit N, De Smet E, De Paepe A, Laureys G, Vandesompele J, Speleman F: High resolution tiling-path BAC array deletion mapping suggests commonly involved 3p21-p22 tumor suppressor genes in neuroblastoma and more frequent tumors. Int J Cancer 2007, 120:533538

53. Longo L, Panza E, Schena F, Seri M, Devoto M, Romeo G, Bini C, Pappalardo G, Tonini GP, Perri P: Genetic predisposition to familial neuroblastoma: identification of two novel genomic regions at $2 p$ and $12 p$. Hum Hered 2007, 63:205211

54. Shojaei-Brosseau T, Chompret $A$, Abel $A$, de Vathaire $F$, Raquin MA, Brugieres L, Feunteun J, Hartmann O, Bonaiti-Pellie C: Genetic epidemiology of neuroblastoma: a study of 426 cases at the Institut Gustave-Roussy in France. Pediatr Blood Cancer 2004, 42:99-105.

55. Knudson AG Jr, Strong LC: Mutation and cancer: neuroblastoma and pheochromocytoma. Am J Hum Genet 1972, 24: 514-532.

56. Amiel J, Laudier B, Attie-Bitach $\mathrm{T}$, Trang $\mathrm{H}$, de Pontual L, Gener B, Trochet D, Etchevers H, Ray P, Simonneau M, Vekemans M, Munnich A, Gaultier C, Lyonnet S: Polyalanine expansion and frameshift mutations of the paired-like homeobox gene PHOX2B in congenital central hypoventilation syndrome. Nat Genet 2003, 33:459-461.

57. Mosse YP, Laudenslager M, Khazi D, Carlisle AJ, Winter CL, Rappaport E, Maris JM: Germline PHOX2B mutation in hereditary neuroblastoma. Am J Hum Genet 2004, 75:727730.

58. Trochet D, Bourdeaut F, Janoueix-Lerosey I, Deville A, de Pontual L, Schleiermacher G, Coze C, Philip N, Frebourg T, Munnich A, Lyonnet S, Delattre O, Amiel J: Germline mutations of the paired-like homeobox 2B (PHOX2B) gene in neuroblastoma. Am J Hum Genet 2004, 74:761-764.

59. Mosse YP, Laudenslager M, Longo L, Cole KA, Wood A, Attiyeh EF, Laquaglia MJ, Sennett R, Lynch JE, Perri P, Laureys G, Speleman F, Kim C, Hou C, Hakonarson H, Torkamani A, Schork NJ, Brodeur GM, Tonini GP, Rappaport E, Devoto M, Maris JM: Identification of ALK as a major familial neuroblastoma predisposition gene. Nature 2008, 455:930-935.

60. Caren H, Abel F, Kogner P, Martinsson T: High incidence of DNA mutations and gene amplifications of the ALK gene in advanced sporadic neuroblastoma tumours. Biochem $J$ 2008, 416:153-159.

61. Chen Y, Takita J, Choi YL, Kato M, Ohira M, Sanada M, Wang L, Soda M, Kikuchi A, Igarashi T, Nakagawara A, Hayashi Y, Mano $\mathrm{H}$, Ogawa S: Oncogenic mutations of ALK kinase in neuroblastoma. Nature 2008, 455:971-974.
62. George RE, Sanda T, Hanna M, Frohling $S$, Luther $W$ 2nd, Zhang J, Ahn Y, Zhou W, London WB, McGrady P, Xue L, Zozulya S, Gregor VE, Webb TR, Gray NS, Gilliland DG, Diller L, Greulich H, Morris SW, Meyerson M, Look AT: Activating mutations in ALK provide a therapeutic target in neuroblastoma. Nature 2008, 455:975-978.

63. Janoueix-Lerosey I, Lequin D, Brugieres L, Ribeiro A, de Pontual L, Combaret V, Raynal V, Puisieux A, Schleiermacher G, Pierron G, Valteau-Couanet D, Frebourg T, Michon J, Lyonnet S, Amiel J, Delattre O: Somatic and germline activating mutations of the ALK kinase receptor in neuroblastoma. Nature 2008, 455:967-970.

64. Maris JM, Mosse YP, Bradfield JP, Hou C, Monni S, Scott RH, Asgharzadeh S, Attiyeh EF, Diskin SJ, Laudenslager M, Winter C, Cole KA, Glessner JT, Kim C, Frackelton EC, Casalunovo T, Eckert AW, Capasso M, Rappaport EF, McConville C, London WB, Seeger RC, Rahman N, Devoto M, Grant SF, Li H, Hakonarson $\mathrm{H}$ : Chromosome $6 \mathrm{p} 22$ locus associated with clinically aggressive neuroblastoma. N Engl J Med 2008, 358:2585-2593.

65. Capasso M, Devoto M, Hou C, Asgharzadeh S, Glessner JT, Attiyeh EF, Mosse YP, Kim C, Diskin SJ, Cole KA, Bosse K, Diamond M, Laudenslager M, Winter C, Bradfield JP, Scott RH, Jagannathan J, Garris M, McConville C, London WB, Seeger RC, Grant SF, Li H, Rahman N, Rappaport E, Hakonarson H, Maris JM: Common variations in BARD1 influence susceptibility to high-risk neuroblastoma. Nat Genet 2009, 41:718723.

66. Wu LC, Wang ZW, Tsan JT, Spillman MA, Phung A, Xu XL, Yang MC, Hwang LY, Bowcock AM, Baer R: Identification of a RING protein that can interact in vivo with the BRCA1 gene product. Nat Genet 1996, 14:430-440.

67. Kallioniemi OP, Kallioniemi A, Piper J, Isola J, Waldman FM, Gray JW, Pinkel D: Optimizing comparative genomic hybridization for analysis of DNA sequence copy number changes in solid tumors. Genes Chromosomes Cancer 1994 10:231-243

68. Michels E, Vandesompele J, De Preter K, Hoebeeck J, Vermeulen J, Schramm A, Molenaar JJ, Menten B, Marques B Stallings RL, Combaret V, Devalck C, De Paepe A, Versteeg R, Eggert A, Laureys G, Van Roy N, Speleman F: ArrayCGHbased classification of neuroblastoma into genomic subgroups. Genes Chromosomes Cancer 2007, 46:1098-1108.

69. Janoueix-Lerosey I, Schleiermacher G, Michels E, Mosseri V, Ribeiro A, Lequin D, Vermeulen J, Couturier J, Peuchmaur M, Valent A, Plantaz D, Rubie H, Valteau-Couanet D, Thomas C, Combaret V, Rousseau R, Eggert A, Michon J, Speleman F Delattre O: Overall genomic pattern is a predictor of outcome in neuroblastoma. J Clin Oncol 2009, 27:10261033.

70. Mosse YP, Diskin SJ, Wasserman N, Rinaldi K, Attiyeh EF, Cole K, Jagannathan J, Bhambhani K, Winter C, Maris JM: Neuroblastomas have distinct genomic DNA profiles that predict clinical phenotype and regional gene expression. Genes Chromosomes Cancer 2007, 46:936-949.

71. Vandesompele J, Van Roy N, Van Gele M, Laureys G, Ambros P, Heimann P, Devalck C, Schuuring E, Brock P, Otten J, Gyselinck J, De Paepe A, Speleman F: Genetic heterogeneity of neuroblastoma studied by comparative genomic hybridization. Genes Chromosomes Cancer 1998, 23:141-152.

72. Michels E, De Preter K, Van Roy N, Speleman F: Detection of DNA copy number alterations in cancer by array comparative genomic hybridization. Genet Med 2007, 9:574-584

73. Tomioka N, Oba S, Ohira M, Misra A, Fridlyand J, Ishii S, Nakamura Y, Isogai E, Hirata T, Yoshida Y, Todo S, Kaneko Y, Albertson DG, Pinkel D, Feuerstein BG, Nakagawara A: Novel risk stratification of patients with neuroblastoma by genomic signature, which is independent of molecular signature. Oncogene 2008, 27:441-449.

74. Asgharzadeh $S$, Pique-Regi $R$, Sposto $R$, Wang $H$, Yang $Y$ Shimada H, Matthay K, Buckley J, Ortega A, Seeger RC: Prognostic significance of gene expression profiles of metastatic neuroblastomas lacking MYCN gene amplification. J Natl Cancer Inst 2006, 98:1193-1203. 
75. Oberthuer A, Berthold F, Warnat P, Hero B, Kahlert $Y$, Spitz R, Ernestus K, Konig R, Haas S, Eils R, Schwab M, Brors B, Westermann F, Fischer M: Customized oligonucleotide microarray gene expression-based classification of neuroblastoma patients outperforms current clinical risk stratification. J Clin Oncol 2006, 24:5070-5078.

76. Ohira M, Oba S, Nakamura Y, Isogai E, Kaneko S, Nakagawa A, Hirata T, Kubo H, Goto T, Yamada S, Yoshida Y, Fuchioka M, Ishii $S$, Nakagawara A: Expression profiling using a tumorspecific cDNA microarray predicts the prognosis of intermediate risk neuroblastomas. Cancer Cell 2005, 7:337-350.

77. Schramm A, Schulte JH, Klein-Hitpass L, Havers W, Sieverts $\mathrm{H}$, Berwanger B, Christiansen $\mathrm{H}$, Warnat $\mathrm{P}$, Brors B, Eils J, Eils $R$, Eggert A: Prediction of clinical outcome and biological characterization of neuroblastoma by expression profiling. Oncogene 2005, 24:7902-7912.

78. Wei JS, Greer BT, Westermann F, Steinberg SM, Son CG, Chen QR, Whiteford CC, Bilke S, Krasnoselsky AL, Cenacchi N, Catchpoole D, Berthold F, Schwab M, Khan J: Prediction of clinical outcome using gene expression profiling and artificial neural networks for patients with neuroblastoma. Cancer Res 2004, 64:6883-6891.

79. Berwanger B, Hartmann O, Bergmann E, Bernard S, Nielsen $D$, Krause M, Kartal A, Flynn D, Wiedemeyer R, Schwab M, Schafer $\mathrm{H}$, Christiansen $\mathrm{H}$, Eilers M: Loss of a FYN-regulated differentiation and growth arrest pathway in advanced stage neuroblastoma. Cancer Cell 2002, 2:377-386.

80. Vermeulen J, De Preter K, Naranjo A, Vercruysse L, Van Roy N, Hellemans J, Swerts K, Bravo S, Scaruffi P, Tonini GP, De Bernardi B, Noguera R, Piqueras M, Canete A, Castel V, Janoueix-Lerosey I, Delattre O, Schleiermacher G, Michon J, Combaret V, Fischer M, Oberthuer A, Ambros PF, Beiske K, Benard J, Marques B, Rubie $\mathrm{H}$, Kohler J, Potschger U, Ladenstein $\mathrm{R}$, et al.: Predicting outcomes for children with neuroblastoma using a multigene-expression signature: a retrospective SIOPEN/COG/GPOH study. Lancet Oncol 2009, 10:663-671.

81. De Preter K, Vandesompele J, Heimann P, Yigit N, Beckman S, Schramm A, Eggert A, Stallings RL, Benoit $Y$, Renard M, De Paepe A, Laureys G, Pahlman S, Speleman F: Human fetal neuroblast and neuroblastoma transcriptome analysis confirms neuroblast origin and highlights neuroblastoma candidate genes. Genome Biol 2006, 7:R84.

82. Lamb J, Crawford ED, Peck D, Modell JW, Blat IC, Wrobel MJ, Lerner J, Brunet JP, Subramanian A, Ross KN, Reich M, Hieronymus $\mathrm{H}$, Wei G, Armstrong SA, Haggarty SJ, Clemons PA, Wei R, Carr SA, Lander ES, Golub TR: The Connectivity Map: using gene-expression signatures to connect small molecules, genes, and disease. Science 2006, 313:19291935.

83. De Preter K, De Brouwer S, Van Maerken T, Pattyn F, Schramm A, Eggert A, Vandesompele J, Speleman F: Meta-mining of neuroblastoma and neuroblast gene expression profiles reveals candidate therapeutic compounds. Clin Cancer Res 2009, 15:3690-3696.

84. Ongenaert M, Van Neste L, De Meyer T, Menschaert G, Bekaert S, Van Criekinge W: PubMeth: a cancer methylation database combining text-mining and expert annotation. Nucleic Acids Res 2008, 36:D842- D846.

85. Abe M, Ohira M, Kaneda A, Yagi Y, Yamamoto S, Kitano Y, Takato T, Nakagawara A, Ushijima T: CpG island methylator phenotype is a strong determinant of poor prognosis in neuroblastomas. Cancer Res 2005, 65:828-834.

86. Alaminos M, Davalos V, Cheung NK, Gerald WL, Esteller M: Clustering of gene hypermethylation associated with clinical risk groups in neuroblastoma. J Natl Cancer Inst 2004, 96:1208-1219.

87. Banelli B, Gelvi I, Di Vinci A, Scaruffi P, Casciano I, Allemanni G, Bonassi S, Tonini GP, Romani M: Distinct CpG methylation profiles characterize different clinical groups of neuroblastic tumors. Oncogene 2005, 24:5619-5628.

88. Hoebeeck J, Michels E, Pattyn F, Combaret V, Vermeulen J, Yigit N, Hoyoux C, Laureys G, De Paepe A, Speleman F, Vandesompele $\mathrm{J}$ : Aberrant methylation of candidate tumor suppressor genes in neuroblastoma. Cancer Lett 2009, 273: 336-346.

89. Yang $Q$, Kiernan CM, Tian $Y$, Salwen HR, Chlenski A, Brumback BA, London WB, Cohn SL: Methylation of CASP8, DCR2, and HIN-1 in neuroblastoma is associated with poor outcome. Clin Cancer Res 2007, 13:3191-3197.

90. Misawa A, Tanaka S, Yagyu S, Tsuchiya K, lehara T, Sugimoto T, Hosoi H: RASSF1A hypermethylation in pretreatment serum DNA of neuroblastoma patients: a prognostic marker. Br J Cancer 2009, 100:399-404.

91. Yagyu S, Gotoh T, lehara T, Miyachi M, Katsumi Y, TsubaiShimizu S, Kikuchi K, Tamura S, Tsuchiya K, Imamura T, Misawa-Furihata A, Sugimoto T, Sawada T, Hosoi $H$ : Circulating methylated-DCR2 gene in serum as an indicator of prognosis and therapeutic efficacy in patients with MYCN nonamplified neuroblastoma. Clin Cancer Res 2008, 14:7011-7019.

92. Esquela-Kerscher A, Slack FJ: Oncomirs - microRNAs with a role in cancer. Nat Rev Cancer 2006, 6:259-269.

93. Chen $Y$, Stallings RL: Differential patterns of microRNA expression in neuroblastoma are correlated with prognosis, differentiation, and apoptosis. Cancer Res 2007, 67: 976-983.

94. Lu J, Getz G, Miska EA, Alvarez-Saavedra E, Lamb J, Peck D, Sweet-Cordero A, Ebert BL, Mak RH, Ferrando AA, Downing JR, Jacks T, Horvitz HR, Golub TR: MicroRNA expression profiles classify human cancers. Nature 2005, 435:834-838.

95. Schulte JH, Horn S, Otto T, Samans B, Heukamp LC, Eilers UC, Krause M, Astrahantseff K, Klein-Hitpass L, Buettner R, Schramm A, Christiansen H, Eilers M, Eggert A, Berwanger B: MYCN regulates oncogenic microRNAs in neuroblastoma. Int J Cancer 2008, 122:699-704.

96. Otto T, Horn S, Brockmann M, Eilers U, Schuttrumpf L, Popov $\mathrm{N}$, Kenney AM, Schulte JH, Beijersbergen R, Christiansen $\mathrm{H}$, Berwanger $\mathrm{B}$, Eilers $\mathrm{M}$ : Stabilization of $\mathrm{N}$-Myc is a critical function of Aurora A in human neuroblastoma. Cancer Cell 2009, 15:67-78.

97. Hayashita $\mathrm{Y}$, Osada $\mathrm{H}$, Tatematsu $\mathrm{Y}$, Yamada H, Yanagisawa $\mathrm{K}$, Tomida S, Yatabe Y, Kawahara K, Sekido Y, Takahashi T: A polycistronic microRNA cluster, miR-17-92, is overexpressed in human lung cancers and enhances cell proliferation. Cancer Res 2005, 65:9628-9632.

98. O'Donnell KA, Wentzel EA, Zeller KI, Dang CV, Mendell JT: c-Myc-regulated microRNAs modulate E2F1 expression. Nature 2005, 435:839-843.

99. Uziel T, Karginov FV, Xie S, Parker JS, Wang YD, Gajjar A, He L, Ellison D, Gilbertson RJ, Hannon G, Roussel MF: The miR17 92 cluster collaborates with the Sonic Hedgehog pathway in medulloblastoma. Proc Natl Acad Sci USA 2009, 106:2812-2817.

100. Fontana L, Fiori ME, Albini S, Cifaldi L, Giovinazzi S, Forloni M, Boldrini R, Donfrancesco A, Federici V, Giacomini P, Peschle C, Fruci D: Antagomir-17-5p abolishes the growth of therapy-resistant neuroblastoma through p21 and BIM. PLOS ONE 2008, 3:e2236.

101. Wei JS, Song YK, Durinck S, Chen QR, Cheuk AT, Tsang $P$ Zhang Q, Thiele CJ, Slack A, Shohet J, Khan J: The MYCN oncogene is a direct target of miR-34a. Oncogene 2008, 27: 5204-5213.

102. Bilke S, Chen QR, Wei JS, Khan J: Whole chromosome alterations predict survival in high-risk neuroblastoma without MYCN amplification. Clin Cancer Res 2008, 14:5540-5547.

103. Welch $C$, Chen $Y$, Stallings RL: MicroRNA-34a functions as a potential tumor suppressor by inducing apoptosis in neuroblastoma cells. Oncogene 2007, 26:5017-5022.

104. Maris JM, Hogarty MD, Bagatell R, Cohn SL: Neuroblastoma. Lancet 2007, 369:2106-2120.

105. Wagner LM, Danks MK: New therapeutic targets for the treatment of high-risk neuroblastoma. J Cell Biochem 2009, 107:46-57.

106. Darnell JE Jr: Transcription factors as targets for cancer therapy. Nat Rev Cancer 2002, 2:740-749. 
107. Lu X, Pearson A, Lunec J: The MYCN oncoprotein as a drug development target. Cancer Lett 2003, 197:125-130.

108. Mo H, Henriksson M: Identification of small molecules that induce apoptosis in a Myc-dependent manner and inhibit Myc-driven transformation. Proc Natl Acad Sci USA 2006, 103:6344-6349.

109. Mo H, Vita M, Crespin M, Henriksson M: Myc overexpression enhances apoptosis induced by small molecules. Cell Cycle 2006, 5:2191-2194.

110. Burkhart CA, Cheng AJ, Madafiglio J, Kavallaris M, Mili M, Marshall GM, Weiss WA, Khachigian LM, Norris MD, Haber M: Effects of MYCN antisense oligonucleotide administration on tumorigenesis in a murine model of neuroblastoma. $J$ Natl Cancer Inst 2003, 95:1394-1403.

111. Negroni A, Scarpa S, Romeo A, Ferrari S, Modesti A, Raschella $G$ : Decrease of proliferation rate and induction of differentiation by a MYCN antisense DNA oligomer in a human neuroblastoma cell line. Cell Growth Differ 1991, 2:511-518.

112. Kang JH, Rychahou PG, Ishola TA, Qiao J, Evers BM, Chung $\mathrm{DH}$ : MYCN silencing induces differentiation and apoptosis in human neuroblastoma cells. Biochem Biophys Res Commun 2006, 351:192-197.

113. Nara K, Kusafuka T, Yoneda A, Oue T, Sangkhathat S, Fukuzawa M: Silencing of MYCN by RNA interference induces growth inhibition, apoptotic activity and cell differentiation in a neuroblastoma cell line with MYCN amplification. Int J Oncol 2007, 30:1189-1196.

114. Caren H, Erichsen J, Olsson L, Enerback C, Sjoberg RM, Abrahamsson J, Kogner $\mathrm{P}$, Martinsson $\mathrm{T}$ : High-resolution array copy number analyses for detection of deletion, gain, amplification and copy-neutral LOH in primary neuroblastoma tumors: four cases of homozygous deletions of the CDKN2A gene. BMC Genomics 2008, 9:353.

115. Carr J, Bell E, Pearson AD, Kees UR, Beris H, Lunec J, Tweddle DA: Increased frequency of aberrations in the p53/ MDM2/p14(ARF) pathway in neuroblastoma cell lines established at relapse. Cancer Res 2006, 66:2138-2145.

116. Cattelani S, Defferrari R, Marsilio S, Bussolari R, Candini O, Corradini F, Ferrari-Amorotti G, Guerzoni C, Pecorari L, Menin C, Bertorelle R, Altavista P, McDowell HP, Boldrini R, Dominici C, Tonini GP, Raschella G, Calabretta B: Impact of a single nucleotide polymorphism in the MDM2 gene on neuroblastoma development and aggressiveness: results of a pilot study on 239 patients. Clin Cancer Res 2008, 14:3248-3253.

117. Cui H, Hu B, Li T, Ma J, Alam G, Gunning WT, Ding HF: Bmi-1 is essential for the tumorigenicity of neuroblastoma cells. Am J Pathol 2007, 170:1370-1378.

118. Perfumo C, Parodi S, Mazzocco K, Defferrari R, Inga A, Haupt R, Fronza G, Tonini GP: Impact of MDM2 SNP309 genotype on progression and survival of stage 4 neuroblastoma. Eur $J$ Cancer 2008, 44:2634-2639.

119. Slack A, Chen Z, Tonelli R, Pule M, Hunt L, Pession A, Shohet JM: The p53 regulatory gene MDM2 is a direct transcrip- tional target of MYCN in neuroblastoma. Proc Natl Acad Sci USA 2005, 102:731-736.

120. Thompson PM, Maris JM, Hogarty MD, Seeger RC, Reynolds CP, Brodeur GM, White PS: Homozygous deletion of CDKN2A (p16INK4a/p14ARF) but not within $1 \mathrm{p} 36$ or at other tumor suppressor loci in neuroblastoma. Cancer Res 2001, 61:679-686.

121. Valsesia-Wittmann S, Magdeleine M, Dupasquier S, Garin E, Jallas AC, Combaret $V$, Krause $A$, Leissner $P$, Puisieux $A$ : Oncogenic cooperation between $\mathrm{H}$-Twist and $\mathrm{N}$-Myc overrides failsafe programs in cancer cells. Cancer Cell 2004, 6:625-630.

122. Vassilev LT, Vu BT, Graves B, Carvajal D, Podlaski F, Filipovic Z, Kong N, Kammlott U, Lukacs C, Klein C, Fotouhi N, Liu EA In vivo activation of the p53 pathway by small-molecule antagonists of MDM2. Science 2004, 303:844-848.

123. Van Maerken T, Speleman F, Vermeulen J, Lambertz I, De Clercq S, De Smet E, Yigit N, Coppens V, Philippe J, De Paepe A, Marine JC, Vandesompele J: Small-molecule MDM2 antagonists as a new therapy concept for neuroblastoma. Cancer Res 2006, 66:9646-9655.

124. Barbieri E, Mehta P, Chen Z, Zhang L, Slack A, Berg S, Shohet JM: MDM2 inhibition sensitizes neuroblastoma to chemotherapy-induced apoptotic cell death. Mol Cancer Ther 2006, 5:2358-2365.

125. Michaelis $M$, Rothweiler F, Klassert D, von Deimling A, Weber K, Fehse B, Kammerer B, Doerr HW, Cinatl J Jr: Reversal of P-glycoprotein-mediated multidrug resistance by the murine double minute 2 antagonist nutlin-3. Cancer Res 2009, 69:416-421.

126. Osajima-Hakomori $Y$, Miyake I, Ohira M, Nakagawara A, Nakagawa $A$, Sakai R: Biological role of anaplastic lymphoma kinase in neuroblastoma. Am J Pathol 2005, 167: 1-7-X 213-222.

127. Zhang J, Yang PL, Gray NS: Targeting cancer with small molecule kinase inhibitors. Nat Rev Cancer 2009, 9:28-39.

128. McDermott U, lafrate AJ, Gray NS, Shioda T, Classon M, Maheswaran S, Zhou W, Choi HG, Smith SL, Dowell L, Ulkus LE, Kuhlmann G, Greninger P, Christensen JG, Haber DA, Settleman J: Genomic alterations of anaplastic lymphoma kinase may sensitize tumors to anaplastic lymphoma kinase inhibitors. Cancer Res 2008, 68:3389-3395.

129. Li R, Morris SW: Development of anaplastic lymphoma kinase (ALK) small-molecule inhibitors for cancer therapy. Med Res Rev 2008, 28:372-412.

Published: 27 July 2009

doi:10.1186/gm74

(c) 2009 BioMed Central Ltd 